\title{
In Vivo and In Vitro Evaluation of Pharmacological Potentials of Secondary Bioactive Metabolites of Dalbergia candenatensis Leaves
}

\author{
Md. Anisuzzman, Md. Mahedi Hasan, Amit Kumar Acharzo, \\ Asish Kumar Das, and Sinthia Rahman \\ Pharmacy Discipline, Life Science School, Khulna University, Khulna 9208, Bangladesh \\ Correspondence should be addressed to Md. Anisuzzman; anisuzzman1984@gmail.com
}

Received 18 June 2017; Revised 9 September 2017; Accepted 25 October 2017; Published 26 December 2017

Academic Editor: Laura De Martino

Copyright ( $) 2017 \mathrm{Md}$. Anisuzzman et al. This is an open access article distributed under the Creative Commons Attribution License, which permits unrestricted use, distribution, and reproduction in any medium, provided the original work is properly cited.

Background. Dalbergia species has wide range of secondary metabolites and is traditionally used in treatment of painful micturition, swelling, and leprosy and as blood tonic. The study evaluates membrane stabilizing, anticoagulant, analgesic, cytotoxic, subacute anti-inflammatory, and depression potentials of $D$. candenatensis leaves metabolites. Methods. Membrane stabilizing activity was evaluated by hypotonic induced hemolysis assay, whereas anticoagulant activity is done through extrinsic pathway by measuring prothrombin time. Analgesic action, cytotoxic effect, and subacute anti-inflammatory activity were determined by acetic acid induced writhing model, brine shrimp lethality bioassay, and formaldehyde induced model, respectively. Depression activity was measured by the Open Field, Hole Cross, Hole Board, and thiopentone induced sleeping time measuring methods. Results. D. candenatensis contains phenolic, flavonoid, and tannin, quantified as $416.25 \mathrm{mg}, 330.00 \mathrm{mg}$, and $432.22 \mathrm{mg}$ Gallic Acid Equivalent $/ 100 \mathrm{~g}$ of dry extract, respectively. Extract showed maximum inhibition of writhe, hemolysis, and edema, approximate to $57.14 \%, 36.62 \%$, and $34.1 \%$, respectively. $\mathrm{LC}_{50}$ value for nauplii was $151.499 \mu \mathrm{g} / \mathrm{ml}$. Mean prothrombin time was approximate to 31.0 \pm 2.31 seconds at $1.0 \mathrm{mg} / \mathrm{ml}$. Extract showed depression activity, and maximum sleeping time was noted to be about 141 minutes. Conclusion. D. candenatensis leaves show dose dependent membrane stabilizing, anticoagulant, depression, analgesic, moderate cytotoxic, and subacute anti-inflammatory activities.

\section{Introduction}

From time immemorial, men have used several natural sources to combat with diseases rather than concede the fate of diseases [1]. Among many natural sources, men have been using plants mostly because of its availability and routinely used as foods or other purposes. Moreover, it is believed that natural product derived from plants may have fewer side effects to life [2]. The perception of therapeutic use of plants has continued with the development of human civilization and knowledge. Scientists have been trying hard to isolate different chemical compounds from plants to identify therapeutically active compounds based on various biological and pharmacological studies. Today, almost 33\% of the drugs produced in the developed countries are derived from plants [3]. In view of this, the present studies were designed for preliminary screening of phytochemicals and evaluation of membrane stabilizing, anticoagulant, analgesic, subacute anti-inflammatory, depression, and cytotoxic activities of leaves of Dalbergia candenatensis Prain. D. candenatensis is a small- to medium-size tree which belongs to Fabaceae family (alternatively known as the Leguminosae). Geographically, the plant widely scattered throughout the world including mangrove forest of Bangladesh $[4,5]$. D. candenatensis is commonly known as Chanda Lota [4]. Various species of Dalbergia are traditionally used in the treatment of different ailments like analgesic, anti-inflammatory, antimicrobial, cough, haemorrhages, and leprosy [5]. The wood of D. candenatensis is used as a blood tonic, expectorant, antifungal, and antibacterial substances [6]. The $\mathrm{CHCl}_{3}$ and $\mathrm{MeOH}$ extracts of heartwood were reportedly found to display antibacterial, antifungal activity, and cytotoxic activity against the P-388 
lymphocytic leukemia test system in vitro [7]. The $\mathrm{CHCl}_{3}$ and $\mathrm{MeOH}$ extracts of heartwood have been reported to possess several types of flavonoids like mucronulatol, claussequinone, 5-hydroxybowdichione, formononetin, and vestitol [7]. The $\mathrm{CH}_{2} \mathrm{Cl}_{2}$ extract of the heartwood of D. candenatensis has been also reported to possess Candenatenin A, Candenatenin B, Candenatenin C, Candenatenin D, Candenatenin E, Candenatenin F, 3,5-dihydroxy-7-methoxyflavanone, 4-hydroxy3-methoxy-8,9-methylenedioxypterocarpan, nutiducol, and sophoraflavanone with cytotoxic activity [6]. The acetone extract of air-dried heartwood of $D$. candenatensis was also investigated to obtain Candenatenin G, Candenatenin H, Candenatenin I, Candenatenin J, Candenatenin K, dinklagin A, stipulin, (R)-4-methoxydalbergione, and melilotocarpan A [6]. The methanol extract of wood of D. candenatensis exhibited significant estrogenic activity on ER $\beta$ [8]. Previous records of phytochemical and biological studies of D. candenatensis except on its wood are scanty. Therefore, present study was concerned with the investigation of membranes stabilizing, anticoagulant, analgesic, subacute antiinflammatory, neuropharmacological, and cytotoxic activity of leaves of Dalbergia candenatensis Prain.

\section{Materials and Methods}

2.1. Plant Collection and Extraction. The leaves of Dalbergia candenatensis were carefully collected from Sundarban, Bangladesh, during the month of January, 2016, at daytime. After collection, the sample was identified by the authorities of Bangladesh National Herbarium, Mirpur, Dhaka, where a voucher specimen (DACB Accession Number 36783) was deposited for further reference. The leaves were washed with fresh water, cut into small pieces, and then shred-dried for up to fourteen days. The dried leaves were grounded into fine powder by means of Capacitor Start Motor, China. The crude extract was obtained by cold extraction method by taking $260 \mathrm{~g}$ powders in $800 \mathrm{ml}$ of $98 \%$ ethanol into a clean and airtight glass vessel for fourteen days at room temperature with occasional shaking and stirring. After aforementioned maceration, mixture was filtered through Whatman filter paper to separate the extract from the plant debris. The extract was concentrated initially by rotary evaporator at reduced pressure and finally by open air. The yield was found to be $5.77 \% \mathrm{w} / \mathrm{w}$.

2.2. Chemicals and Drugs. Diclofenac sodium, Indomethacin, thiopental sodium, and diazepam were collected from Square Pharmaceuticals Ltd., Bangladesh. Warfarin was collected from Incepta Pharmaceuticals Ltd. Vincristine sulphate was collected from Beacon Pharmaceuticals Ltd. All other analytical grade chemicals were purchased from Sigma Chemicals, USA.

2.3. Test Animals. Young healthy Swiss-albino mice aged 45 weeks and rats aged 3-4 months were purchased from The International Centre for Diarrheal Disease Research, Bangladesh. They were kept for seven days in the animal house of the Pharmacy Discipline, Khulna University,
Bangladesh, for adaptation. The animal house was maintained with relative humidity $55 \%-65 \%$, room temperature $25 \pm 2^{\circ} \mathrm{C}$, and $12 / 12 \mathrm{~h}$ light/dark cycle. ICDDR B-formulated diet and purified water were fed to the animals. Brine shrimp nauplii hatched in the laboratory. These animals were treated by following the "Ethical Principles and Guidelines for Scientific Experiments on Animals (1995)" instructed by the Swiss Academy of Medical Sciences and the Swiss Academy of Sciences for the entire experiment period.

2.4. Phytochemical Screening. Phytochemical screening of ethanol extract of leaves of Dalbergia candenatensis was carried out according to standard quantitative procedures [9]. The crude extract was investigated to probe alkaloid, phenolic, steroid, reducing sugar, saponin, tannin, and flavonoids.

2.5. Evaluation of Membrane Stabilizing Activity. Membrane stabilizing activity of $D$. candenatensis was measured by hypotonic induced haemolysis assay $[10,11]$. Fresh blood sample was collected into centrifuge tube containing trisodium citrate $(3.8 \% \mathrm{w} / \mathrm{v})$ and centrifuged at $3,000 \mathrm{rpm}$ for 10 minutes. Then, supernatant was carefully removed by using pipette. The packed erythrocytes were resuspended in fresh $0.9 \%$ sodium chloride and mixed thoroughly followed by centrifugation again for 5 minutes to remove the supernatant as aforementioned. This process continued until clear supernatant was obtained. Then $2 \%(\mathrm{v} / \mathrm{v})$ erythrocyte suspension was prepared by using packed red blood cells with $0.9 \%$ sodium chloride. During experiment, $0.5 \mathrm{ml}$ stock erythrocyte suspension was mixed with $5 \mathrm{ml}$ hypotonic buffer saline (50 mMols sodium chloride in $10 \mathrm{mMols}$ sodium phosphate, $\mathrm{pH}=7.4$ ) into four test tubes and then $1 \mathrm{ml}$ crude extract with concentrations of $0.25,0.50,1.0$, and $2.0 \mathrm{mg} / \mathrm{ml}$ added, respectively. Standard sample was prepared with the mixture of $1 \mathrm{ml}$ Indomethacin of $0.10 \mathrm{mg} / \mathrm{ml}, 0.5 \mathrm{ml}$ stock erythrocyte suspension, and $5 \mathrm{ml}$ hypotonic buffer saline, while the control sample contains only the same volume of distilled water rather than test sample or standard drug. Then, test tubes were incubated for 10 minutes at room temperature. After incubation it was subjected to centrifugation for 10 minutes at 3,000 rpm. Finally, the supernatant was collected and absorbance was measured at $540 \mathrm{~nm}$.

2.6. Evaluation of Anticoagulant Activity. Anticoagulant activity of $D$. candenatensis was measured by using prothrombin time test method [12]. Blood samples were collected from healthy volunteers aged 20-25 to accomplish the experiment. Disposable syringes were used to withdraw blood from volunteer. The blood was taken into centrifuge tubes that previously contained $3.8 \%$ trisodium citrate to inhibit blood coagulation during transportation. The centrifuge test tube was centrifuged at $3,000 \mathrm{rpm}$ for $15 \mathrm{~min}$ to obtain pure platelet plasma. Then the plasma was carefully separated from suspended blood particle and stored at $4^{\circ} \mathrm{C}$ until use. Several concentrations $(0.25,0.50,1.00,2.00$, and $4.00 \mathrm{mg} / \mathrm{ml})$ of D. candenatensis leaves extracts, $0.2 \mathrm{ml}$ test plasma of each individual, and $0.3 \mathrm{ml} \mathrm{CaCl}_{2}$ (25 mMols) were mixed together into a test tube. Then $0.1 \mathrm{ml}$ of $0.9 \%$ saline, $0.2 \mathrm{ml}$ test plasma of each individual, and $0.3 \mathrm{ml} \mathrm{CaCl} 2$ (25 mMols) were mixed 
together into another test tube for negative control whereas $0.1 \mathrm{ml}$ warfarin taken in place of the extract, $0.2 \mathrm{~mL}$ test plasma of each individual, and $0.3 \mathrm{ml} \mathrm{CaCl}_{2}$ (25 mMols) were mixed together into another test tube for positive control. Each tube was incubated at $37^{\circ} \mathrm{C}$ and the clotting of blood samples was inspected visually by tilting the test tube frequently. Each of the tests was carried out 5 times with the clotting time recorded using stopwatch.

2.7. Evaluation of Acute Toxicity. This was performed to determine the safe dose(s) to be used in different tests. The mice were kept in fasting condition for $16 \mathrm{~h}$. The mice were divided into 5 groups each containing 6 mice and the extract was orally administered at the doses of 500, 1,000 1,600, and $2,000 \mathrm{mg} / \mathrm{kg}$ body weight, while the control group received distilled water. The animals were kept $72 \mathrm{~h}$ for observation of death of mice. General signs and symptoms of toxicity were noted for each group according to OECD guide with slight modification $[13,14]$.

2.8. Evaluation of Analgesic Activity. The analgesic activity was evaluated by acetic acid induced writhing model in mice [15]. The experimental animals were randomly divided into five groups having five mice each. The mice of each group were accurately weighed and each experimental group was properly marked. Negative control group received only $1 \%$ (v/v) Tween-80, whereas standard group received standard drug, diclofenac sodium at a dose of $25 \mathrm{mg} / \mathrm{kg}$ body weight as oral suspension. In test groups (I, II, and III), 100, 250, and $500 \mathrm{mg} / \mathrm{kg}$ body weight extracts doses were administered. All doses were given orally with the help of sterile feeding needle. After 30 minutes, (0.7\% v/v) acetic acid solution was administered through intraperitoneal injection (IP injection) to all groups. The mice were rested for few minutes because of better absorption of acetic acid. After 5 minutes, the number of writhings was counted for $15 \mathrm{~min}$. The incomplete writhing was taken as half-writhing, so two half-writhings were taken as full writhing. The number of writhings in the control was supposed to be $100 \%$ and $\%$ inhibition was calculated as follows:

$$
\begin{aligned}
& \text { \% Inhibition of writhing } \\
& \quad=100-\left(\frac{\text { treated mean }}{\text { control mean }}\right) \times 100 .
\end{aligned}
$$

2.9. Evaluation of Cytotoxic Activity. Cytotoxic activity of ethanol extract of leaves of $D$. candenatensis was exploited with brine shrimp lethality bioassay [16]. A total of $38 \mathrm{~g}$ of sea salt was weighed accurately and dissolved in distilled water to make simulated seawater. Seawater was taken into small tank and eggs were poured into it. The small tank was kept at $28^{\circ} \mathrm{C}$ in front of a lamp for two days to incubate the shrimp eggs and to be matured as nauplii. During the experiment, the extracts were dissolved in simulated seawater by using DMSO and serial dilution was performed to obtain solutions of varying concentrations-1, 2, 4, 8, 16, 32, 64, 128, 256 and $512 \mu \mathrm{g} / \mathrm{ml}$. Serial dilution was also performed to obtain varying concentrations of standard drug, Vincristine sulphate $(0.3125,0.625,1.25 .2 .50$ and $5.00 \mu \mathrm{g} / \mathrm{ml})$ by using simulated seawater. Then extract or standard drug in different desire concentrations were then added to the premarked test tube containing 10 live brine shrimp nauplii in $10 \mathrm{ml}$ simulated seawater. Simulated seawater with DMSO served as negative control. The test tubes were left uncovered under the lamp and the number of surviving shrimps was counted after 24 hours with the help of magnifying glass and the results were noted. The test was performed in triplicate to avoid statistical error. From this, the percentage of lethality of brine shrimp nauplii was calculated at each concentration following the equation

$$
\% \text { Mortality }=\left[\frac{(\text { Avg. no. of alive shrimp of control }- \text { Avg. no. of alive shrimp of sample })}{\text { Avg. no. of alive shrimp of control }}\right] \times 100
$$

2.10. Evaluation of Subacute Anti-Inflammatory Activity. Formaldehyde induced subacute inflammation model was implemented to evaluate the anti-inflammatory activity of ethanol extract of $D$. candenatensis leaves with slide modification [17]. In this experiment, 25 rats were randomly selected and classified into five different groups termed as negative control group, positive control group, and test groups (I, II, and III). Negative control group received only $1 \%(\mathrm{v} / \mathrm{v})$ Tween- 80 at a dose of $10 \mathrm{ml} / \mathrm{kg}$ body weight, while positive group received standard drug, Indomethacin at a dose of $10 \mathrm{mg} / \mathrm{kg}$ body weight as oral suspension. In the test groups (I, II, and III), extracts were administered at 100, 250, and $500 \mathrm{mg} / \mathrm{kg}$ body weight dose. All doses were given orally with the help of sterile feeding needle. After thirty minutes, the subacute inflammation was induced in all groups by subcutaneous injection of $0.1 \mathrm{ml}$ of $2 \%$ formaldehyde in the right paw of each rat. The linear circumference of the injected paw was measured at $1 \mathrm{~h}, 2 \mathrm{~h}, 3 \mathrm{~h}, 4 \mathrm{~h}, 24 \mathrm{~h}$, and $48 \mathrm{~h}$ after formaldehyde injection.

The percentage inhibition of edema was calculated as per the following equation:

$$
\% \text { Inhibition of edema }=100 \times\left(l_{0}-\frac{l_{1}}{l_{0}}\right),
$$

where $l_{0}$ is change in paw circumference in control group and $l_{1}$ is change in paw circumference in drug treated group or test group.

\subsection{Evaluation of Neuropharmacological Activity}

2.11.1. Thiopental Sodium Induced Sleeping Time. In these experiments, 25 experimental laboratory mice were arbitrarily chosen and accurately weighed. The mice were divided 
into five groups termed as negative control group, positive control group, and test groups (I, II, and III). Five mice in each group were kept in five cages separately. Each mouse of negative control group received orally $1 \%(\mathrm{v} / \mathrm{v})$ Tween-80 in distilled water at the dose of $10 \mathrm{ml} / \mathrm{kg}$ body weight. The mice of positive control group received standard drug diazepam at the dose of $3 \mathrm{mg} / \mathrm{kg}$ body weight. The mice of each test group (I, II, and III) received crude extract at the doses of 100 , 250 , and $500 \mathrm{mg} / \mathrm{kg}$ body weight. All doses were given orally with the help of feeding needle. After 30 minutes, thiopental sodium $(40 \mathrm{mg} / \mathrm{kg}$ ) was given intraperitoneally to all groups for inducing sleep. The onset time of sleep was noted for all the animals. After induction of sleep, mice were placed in the inverted position and when sedation was over, the mice came to normal posture, and time was noted. The interval between loss and recovery of righting reflex was used as index of hypnotic effect. The time interval between injection of thiopental sodium and start of sleep was recorded as latency time [18].

2.11.2. Open Field Test. In this experiment, 25 mice were arbitrary chosen and divided into five different groups termed as negative control group, positive control group, and test groups (I, II, and III). Negative control group received only $1 \%(\mathrm{v} / \mathrm{v})$ Tween-80 at a dose of $10 \mathrm{ml} / \mathrm{kg}$ body weight, while positive group received standard drug, diazepam at a dose of $3 \mathrm{mg} / \mathrm{kg}$ body weight as oral suspension. The test groups (I, II, and III) were treated with suspension of plant extracts at the oral dose of 100,250 , and $500 \mathrm{mg} / \mathrm{kg}$ body weight. All doses were given orally with the help of sterile feeding. After respective treatment, animals were placed individually in one of the corners of square grids $(100 \mathrm{~cm} \times 100 \mathrm{~cm} \times$ $40 \mathrm{~cm}$ ). The number of squares traveled by the mice was monitored for $3 \mathrm{~min}$ at $0,30,60,90$, and 120 minutes during the observation period. During the experiment silent environment was strongly maintained [19].

2.11.3. Hole Board Test. Mice were divided into 5 groups and each group comprised 5 mice with $20-25 \mathrm{~g}$ in weight. Group I was given 1\% Tween-80, Group II was treated with diazepam at $3 \mathrm{mg} / \mathrm{kg}$ body weight dose, and Groups III, IV, and $\mathrm{V}$ termed as test groups were given ethanol extract of D. candenatensis at the doses of 100,250 , and $500 \mathrm{mg} / \mathrm{kg}$ body weight, respectively. At the beginning of the test, mouse was placed in the edge of the board. The number of head dips into the holes was counted as the measurement for a period of 3 minutes on $0,30,60,90$, and 120 minutes for the entire observation period. The experiment was carried out in a sound attenuated room [20].

2.11.4. Hole Cross Test. After respective treatment of aforementioned group, mice were placed individually in the darker chamber of the box, segregated by a wall with hole into dark and white chambers. The total number of crosses through the hole from one chamber to the other by the mouse of each group within 3 minutes was counted on $0,30,60,90$, and 120 minutes. The experiment was conducted in a sound attenuated room [21].
2.12. Data Analysis. " $t$ " test was applied for unpaired data and comparing more than two samples, the analysis of variance (ANOVA) test was applied. The $\mathrm{LC}_{50}$ value of brine shrimp lethality bioassay was calculated with the help of probit analysis software (Ldp line software, USA). Data obtained from this study were expressed as mean \pm SEM. $p$ values less than 0.05 were statistically significant.

\section{Results}

3.1. Phytochemical Screening. The crude ethanol extract of D. candenatensis was subjected for chemical group tests and revealed the presence of reducing sugar, tannin, phenolic, flavonoid, steroid, alkaloid, glycoside, and protein and absence of saponin. Extract was quantified as 416.25, 330.00, and $432.22 \mathrm{mg}$ Gallic Acid Equivalent/100 g dry extract of phenolic, flavonoid, and tannin content, respectively.

3.2. Membrane Stabilizing Activity. Ethanol extract of D. candenatensis leaves exhibited dose dependent inhibition of hemolysis. Compared to control, maximum inhibition was found at $2.0 \mathrm{mg} / \mathrm{ml}$ and lowest inhibition was found at $0.25 \mathrm{mg} / \mathrm{ml}$ (Table 1$)$.

3.3. Evaluation of Anticoagulant Activity. In prothrombin time test, different concentration of extracts produced increased clotting times in a dose dependent manner. For evaluation of anticoagulant activity, at $2.0 \mathrm{mg} / \mathrm{ml}$ and $4.0 \mathrm{mg} /$ $\mathrm{ml}$ doses, the mean prothrombin time of blood was measured at 67 and 176 seconds, respectively, which were comparable to warfarin at $0.1 \mathrm{mg} / \mathrm{ml}$ (Table 2).

3.4. Evaluation of Analgesic Activity. The crude extract exhibited $23.47 \%, 40.82 \%$, and $57.14 \%$ writhing inhibition in mice at oral doses of 100,250 , and $500 \mathrm{mg} / \mathrm{kg}$ body weights of mice, respectively. On the other hand, the standard drug Diclofenac sodium exhibited inhibition of $76.53 \%$ at $25 \mathrm{mg} / \mathrm{kg}$ body weight dose (Table 3 ).

3.5. Evaluation of Cytotoxic Activity. The mortality rate of brine shrimp was increased proportionally with increased concentration of the sample. An approximate linear correlation obtained by plotting percent mortality versus log concentration on the graph paper. The crude extract and standard (Vincristine sulphate) showed $50 \%$ mortality $\left(\mathrm{LC}_{50}\right)$ of brine shrimp nauplii at concentration of $151.499 \mu \mathrm{g} / \mathrm{ml}$ (Figure 1) and $0.645 \mu \mathrm{g} / \mathrm{ml}$, respectively (Figure 2).

Supplementary data associated with this figure is available here.

3.6. Evaluation of Anti-Inflammatory Activity. The swelling induced by formaldehyde was significantly $(p<0.05)$ reduced by the crude ethanol extract in a dose dependent manner. The extract exhibited highest reduction of the size of the edema by $34.10 \%$ at $500 \mathrm{mg} / \mathrm{kg}$ body weight of rats paw in comparison with Indomethacin that reduced the size of the edema by $51.4 \%$ at $10 \mathrm{mg} / \mathrm{kg}$ body weights of rat after 48 hours (Table 4). 
TABLE 1: Membrane stabilising activity of $D$. candenatensis on hypotonic induced haemolysis (mean \pm SEM, $n=5$ ).

\begin{tabular}{lccc}
\hline Groups & Dose & Optical density (OD) & \% inhibition of haemolysis \\
\hline Negative control (distilled water) & - & $0.71 \pm 0.003$ & - \\
Indomethacin (standard drug) & $0.1 \mathrm{mg} / \mathrm{ml}$ & $0.34 \pm 0.006^{* * *}$ & 52.11 \\
Extract I & $0.25 \mathrm{mg} / \mathrm{ml}$ & $0.65 \pm 0.003^{* * *}$ & 8.45 \\
Extract II & $0.50 \mathrm{mg} / \mathrm{ml}$ & $0.60 \pm 0.003^{* * *}$ & 8.45 \\
Extract III & $1.0 \mathrm{mg} / \mathrm{ml}$ & $0.53 \pm 0.003^{* * *}$ & 25.35 \\
Extract IV & $2.0 \mathrm{mg} / \mathrm{ml}$ & $0.45 \pm 0.003^{* * *}$ & 36.62 \\
\hline
\end{tabular}

${ }^{* * *} p<0.001$, significant compared to control.

TABLE 2: Anticoagulant activity of $D$. candenatensis on prothrombin time (PT) of normal human plasma (mean \pm SEM, $n=5$ ).

\begin{tabular}{lcc}
\hline Sample & $\begin{array}{c}\text { Concentration of } \\
\text { sample }\end{array}$ & $\begin{array}{c}\text { Mean prothrombin } \\
\text { time }(\mathrm{sec})\end{array}$ \\
\hline Control & $\begin{array}{c}0.9 \% \text { sodium } \\
\text { chloride }\end{array}$ & $7.0 \pm 1.15$ \\
\hline Warfarin sodium & $0.1 \mathrm{mg} / \mathrm{ml}$ & $122.0 \pm 2.52^{* * *}$ \\
\hline & $0.25 \mathrm{mg} / \mathrm{ml}$ & $10.67 \pm 1.45$ \\
Ethanolic leaves & $0.50 \mathrm{mg} / \mathrm{ml}$ & $20.33 \pm 2.40^{* *}$ \\
extract of $D$. & $1.0 \mathrm{mg} / \mathrm{ml}$ & $31.0 \pm 2.31^{* * *}$ \\
candenatensis & $2.0 \mathrm{mg} / \mathrm{ml}$ & $67.23 \pm 2.71^{* * *}$ \\
& $4.0 \mathrm{mg} / \mathrm{ml}$ & $176.04 \pm 2.41^{* * *}$ \\
\hline
\end{tabular}

${ }^{* *} p<0.01$ and ${ }^{* * *} p<0.001$, significant compared to control.

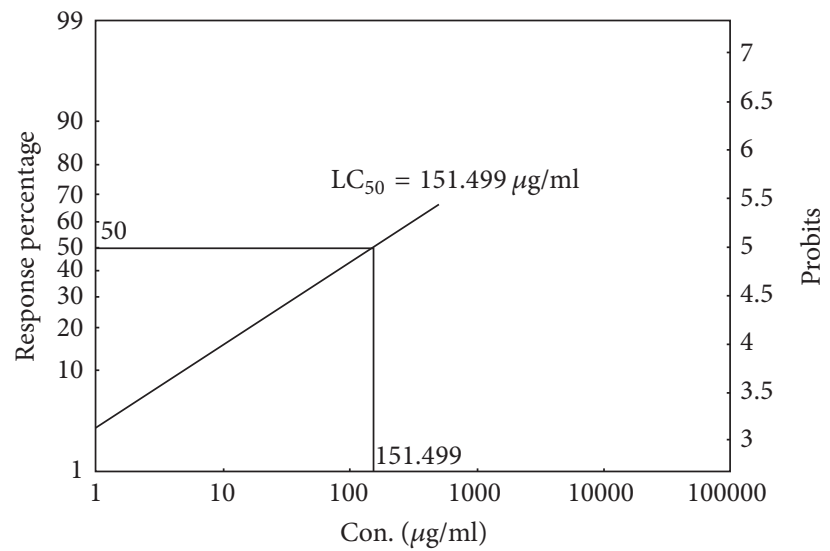

Figure 1: Cytotoxic effect of ethanolic leaves extract of $D$. candenatensis.

\subsection{Evaluation of Neuropharmacological Activity}

3.7.1. Evaluation of Thiopental Sodium Induced Sleeping Time. The ethanol extracts of $D$. candenatensis statistically significantly reduced the time for the onset of sleep and increased the duration of sleep as compared to the control in dose dependent manner. The maximum duration of sleep time was observed to be 141 minutes at $500 \mathrm{mg} / \mathrm{kg}$ body weight dose (Table 5).

3.7.2. Open Field Method. The crude extracts displayed statistically significant reduction in the movements in mice as compared to control. The decrease in the movement was

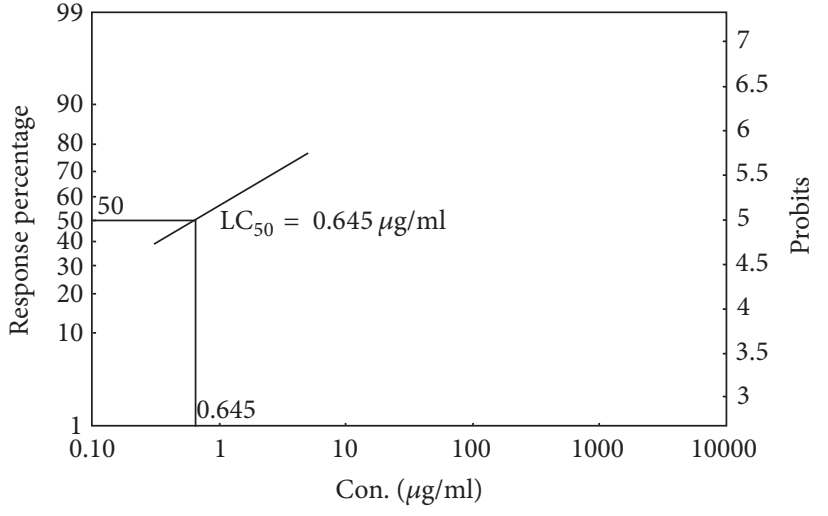

FIGURE 2: Cytotoxic effect of ethanolic solution of standard (Vincristine sulphate).

manifested at 2 nd observation persistent until 4th observation at every tested dose (100, 250, and $500 \mathrm{mg} / \mathrm{kg})$. Diazepam exhibited similar results but the effect was fairly stronger than the extracts (Table 6).

3.7.3. Hole Cross Method. The crude extracts displayed statistically significant reduction of locomotors activity in mice at every tested dose $(100,250$, and $500 \mathrm{mg} / \mathrm{kg})$ compared to control. The decrease in the locomotors activity was manifested at 2nd observation persistent until 4 th observation. Diazepam (positive control) exhibited similar results but the effect was fairly stronger than the extracts (Table 7).

3.7.4. Hole Board Method. In the Hole Board Test, the crude extract at each dose showed significant reduction in the number of head dips compared to control, although the effect of diazepam was strong than that of the results of the crude extracts. The effect was started from 2 nd observation of the experiment and lasted to 4 th observation (Table 8).

3.8. Acute Toxicity Test. In oral acute toxicity test, the highest dose $(2,000 \mathrm{mg} / \mathrm{kg}$ body weight of mice) of the leaves extract did not show any mortality and side effect.

\section{Discussion}

Our preliminary phytochemical screening confirmed the presence of secondary bioactive metabolites such as alkaloids, glycosides, flavonoids, steroids, and tannins in the ethanolic 
TABLE 3: Analgesic activity of $D$. candenatensis on acetic acid-induced writhing in mice (mean \pm SEM, $n=5)$. See supplementary data associated with this table.

\begin{tabular}{lcccc}
\hline Animal groups & Dose & Mean writhing & \% writhing & \% inhibition of writhing \\
\hline Control (1\% v/v Tween-80 water) & $10 \mathrm{ml} / \mathrm{kg}$ & $19.60 \pm 1.81$ & 100 & 0 \\
Diclofenac sodium & $25 \mathrm{mg} / \mathrm{kg}$ & $4.60 \pm 0.68^{*}$ & 23.47 & 76.53 \\
Extract I & $100 \mathrm{mg} / \mathrm{kg}$ & $15.00 \pm 0.71^{*}$ & 76.53 & 23.47 \\
Extract II & $250 \mathrm{mg} / \mathrm{kg}$ & $11.60 \pm 1.08^{*}$ & 59.18 & 40.82 \\
Extract III & $500 \mathrm{mg} / \mathrm{kg}$ & $8.4 \pm 1.33^{*}$ & 42.86 & 57.14 \\
\hline
\end{tabular}

${ }^{*} p<0.05$, significant compared to control.

TABLE 4: Anti-inflammatory activity of $D$. candenatensis on formaldehyde-induced subacute inflammation in rat (mean \pm SEM, $n=5)$. See supplementary data associated with this table.

\begin{tabular}{|c|c|c|c|c|c|c|c|}
\hline \multirow{2}{*}{ Groups } & \multirow{2}{*}{$\begin{array}{c}\text { Dose } \\
(\mathrm{mg} / \mathrm{kg})\end{array}$} & \multicolumn{6}{|c|}{$\begin{array}{l}\text { Mean difference in paw diameter } \\
\text { (\% inhibition) }\end{array}$} \\
\hline & & $1 \mathrm{hr}$ & $2 \mathrm{hr}$ & $3 \mathrm{hr}$ & $4 \mathrm{hr}$ & $24 \mathrm{hr}$ & $48 \mathrm{hr}$ \\
\hline $\begin{array}{l}\text { Control }(1 \% \mathrm{v} / \mathrm{v} \\
\text { Tween- } 80 \text { water })\end{array}$ & $10 \mathrm{ml} / \mathrm{kg}$ & $1.10 \pm 0.0071$ & $1.25 \pm 0.006$ & $1.28 \pm 0.004$ & $1.33 \pm 0.011$ & $1.30 \pm 0.014$ & $1.26 \pm 0.011$ \\
\hline Indomethacin & $10 \mathrm{mg} / \mathrm{kg}$ & $\begin{array}{c}0.82 \pm 0.007^{* * *} \\
(24.4 \%)\end{array}$ & $\begin{array}{c}0.85 \pm 0.004^{* * *} \\
(32 \%)\end{array}$ & $\begin{array}{c}0.45 \pm 0.008^{* * *} \\
(64.84 \%)\end{array}$ & $\begin{array}{c}0.51 \pm 0.007^{* * *} \\
(61.65 \%)\end{array}$ & $\begin{array}{c}0.57 \pm 0.009^{* * *} \\
(56.15 \%)\end{array}$ & $\begin{array}{c}0.61 \pm 0.01^{* * *} \\
(51.5 \%)\end{array}$ \\
\hline Extract I & $100 \mathrm{mg} / \mathrm{kg}$ & $\begin{array}{c}1.05 \pm 0.007^{* * *} \\
(4.5 \%)\end{array}$ & $\begin{array}{c}1.18 \pm 0.007^{* * *} \\
(5.6 \%)\end{array}$ & $\begin{array}{c}1.04 \pm 0.01^{* * *} \\
(18.75 \%)\end{array}$ & $\begin{array}{c}1.11 \pm 0.007^{* * *} \\
(16.54 \%)\end{array}$ & $\begin{array}{c}1.08 \pm 0.009^{* * *} \\
(16.92 \%)\end{array}$ & $\begin{array}{c}1.08 \pm 0.008^{* * *} \\
(14.2)\end{array}$ \\
\hline Extract II & $250 \mathrm{mg} / \mathrm{kg}$ & $\begin{array}{c}1.01 \pm 0.011^{* * *} \\
(8.18 \%)\end{array}$ & $\begin{array}{c}1.11 \pm 0.007^{* * *} \\
(11.2 \%)\end{array}$ & $\begin{array}{c}0.92 \pm 0.009^{* * *} \\
(28.12 \%)\end{array}$ & $\begin{array}{c}0.98 \pm 0.007^{* * *} \\
(26.71 \%)\end{array}$ & $\begin{array}{c}0.97 \pm 0.08^{* * *} \\
(25.38 \%)\end{array}$ & $\begin{array}{c}0.95 \pm 0.01^{* * *} \\
(24.6 \%)\end{array}$ \\
\hline Extract II & $500 \mathrm{mg} / \mathrm{kg}$ & $\begin{array}{c}0.97 \pm 0.007^{* * *} \\
(11.8 \%)\end{array}$ & $\begin{array}{c}1.08 \pm 0.006^{* * *} \\
(13.6 \%)\end{array}$ & $\begin{array}{l}0.81 \pm 0.005^{* * *} \\
\quad(36.71 \%)\end{array}$ & $\begin{array}{l}0.84 \pm 0.011^{* * *} \\
\quad(36.84 \%)\end{array}$ & $\begin{array}{l}0.84 \pm 0.005^{* * *} \\
\quad(35.38 \%)\end{array}$ & $\begin{array}{c}0.82 \pm 0.009^{* * *} \\
(34.9 \%)\end{array}$ \\
\hline
\end{tabular}

$* * *$ indicates $p<0.001$ when compared with control.

TABLE 5: Effect of D. candenatensis on thiopental sodium induced sleeping time in mice (mean $\pm \mathrm{SEM}, n=5$ ).

\begin{tabular}{lccc}
\hline Treatment & $\begin{array}{c}\text { Dose } \\
(\mathrm{mg} / \mathrm{kg})\end{array}$ & $\begin{array}{c}\text { Onset of sleep } \\
(\mathrm{min})\end{array}$ & $\begin{array}{c}\text { Duration of } \\
\text { sleep } \\
(\mathrm{min})\end{array}$ \\
\hline $\begin{array}{l}\text { Control (1\% v/v } \\
\text { Tween-80 water) }\end{array}$ & $10 \mathrm{ml} / \mathrm{kg}$ & $1.94 \pm 0.1$ & $61.60 \pm 3.87$ \\
Diazepam & $3 \mathrm{mg} / \mathrm{kg}$ & $0.81 \pm 0.06$ & $152.60 \pm$ \\
Test I & $100 \mathrm{mg} / \mathrm{kg}$ & $1.75 \pm 0.06$ & $90.40 \pm 3.40^{* * * *}$ \\
Test II & $250 \mathrm{mg} / \mathrm{kg}$ & $1.59 \pm 0.12$ & $113.20 \pm 3.17^{* * *}$ \\
Test III & $500 \mathrm{mg} / \mathrm{kg}$ & $1.30 \pm 0.07$ & $140.60 \pm 3.19^{* * *}$ \\
\hline
\end{tabular}

$* * *$ indicates $p<0.001$ when compared with control.

extract of leaves of Dalbergia candenatensis. The present study investigated the membrane stabilizing, anticoagulant, analgesic, cytotoxic, anti-inflammatory, and neuropharmacological properties of $D$. candenatensis secondary bioactive metabolites. Acute oral administration of ethanolic extract at the higher dose of $2,000 \mathrm{mg} / \mathrm{kg}$ did not display any allergic manifestations or mortality during the observation period of 72 hours after administration. Therefore, it is conceivable that $D$. candenatensis leaves extract may not be toxic at our experimental higher doses up to $2,000 \mathrm{mg} / \mathrm{kg}$ and thus, it ensures good range of therapeutic index.

Erythrocytes lysis means the disruption of integrity of cell membrane. Tissue damage is prevented through inhibition of lysosome stored hydrolytic enzymes release [22]. Phytochemical screening of $D$. candenatensis revealed that plant extracts were rich in flavonoid and tannin which was associated with membrane stabilizing effect because it inhibits the release of lysosomal content of neutrophils at the site of inflammation where erythrocyte membrane may be simulated to the lysosomal membrane and allowed significant protection of the erythrocyte against lysis induced by hypotonic solution [23]. Absence of saponin in plant extracts also prevents blood cell lysis [24]. The highest inhibition was found to be about $36.62 \%$, while the lowest inhibition was approximate to $8.45 \%$ at $0.25 \mathrm{mg} / \mathrm{ml}$ and $2.0 \mathrm{mg} / \mathrm{ml}$ extract dose, respectively. $D$. candenatensis has exhibited outstanding membrane stabilizing activity.

Prothrombin time test measures how long blood takes to clot. In prothrombin time (PT) test, fibrin clot formation in response to tissue injury is the most clinically relevant event of hemostasis under normal physiological conditions. This process is the result of the activation of the extrinsic pathway. So, the agent prolonging the prothrombin time by interfering with blood coagulation pathway is referred to as anticoagulation agent [25]. The prothrombin test specifically evaluates the presence of factors VII, V, and X, prothrombin, and fibrinogen. A prothrombin time within the 7-15-second ranges indicates that the patient has normal amounts of the above clotting factors. A prolonged prothrombin time indicates a deficiency in any of factors VII, X, and V, prothrombin, or fibrinogen. It means that the patient may have a vitamin 
TABLE 6: Effect of D. candenatensis on Open Field test in mice (mean $\pm \mathrm{SEM}, n=5$ ).

\begin{tabular}{lccccc}
\hline \multirow{2}{*}{ Group } & & \multicolumn{3}{c}{ Number of squares crossed by the mice } \\
& 0 min & $30 \mathrm{~min}$ & $60 \mathrm{~min}$ & $90 \mathrm{~min}$ & $120 \mathrm{~min}$ \\
\hline Negative control & $37.5 \pm 3.5$ & $35.5 \pm 2.22$ & $35.5 \pm 3.71$ & $36.5 \pm 3.28$ & $33.25 \pm 3.71$ \\
Positive control & $35.5 \pm 2.5$ & $18.5 \pm 1.32^{* *}$ & $15.0 \pm 1.08^{* * *}$ & $13.5 \pm 1.85^{* * *}$ & $13.25 \pm 1.93^{* * *}$ \\
Test I $(100 \mathrm{mg} / \mathrm{kg})$ & $35.25 \pm 4.57$ & $30.75 \pm 4.03$ & $29.25 \pm 4.80$ & $27.27 \pm 2.46$ & $29.25 \pm 4.83$ \\
Test II $(250 \mathrm{mg} / \mathrm{kg})$ & $36.25 \pm 2.95$ & $30.75 \pm 2.92$ & $26.0 \pm 3.08$ & $25.5 \pm 2.46$ & $26.0 \pm 3.39$ \\
Test III $(500 \mathrm{mg} / \mathrm{kg})$ & $34.5 \pm 2.25$ & $27.0 \pm 3.03$ & $22.5 \pm 2.50^{*}$ & $20.0 \pm 3.85^{* *}$ & $19.25 \pm 3.33^{*}$ \\
\hline
\end{tabular}

$*$ indicates $p<0.05, * *$ indicates $p<0.01$, and $* * *$ indicates $p<0.001$ when compared with control.

TABLE 7: Effect of D. candenatensis on Hole Cross test in mice (mean \pm SEM, $n=5$ ).

\begin{tabular}{|c|c|c|c|c|c|}
\hline \multirow{2}{*}{ Group } & \multicolumn{5}{|c|}{ Number of holes crossed by the mice } \\
\hline & $0 \mathrm{~min}$ & $30 \mathrm{~min}$ & $60 \mathrm{~min}$ & $90 \mathrm{~min}$ & $120 \mathrm{~min}$ \\
\hline Negative control & $6.5 \pm 0.64$ & $6.0 \pm 0.41$ & $5.75 \pm 0.48$ & $5.75 \pm 0.48$ & $5.5 \pm 0.64$ \\
\hline Positive control & $6.75 \pm 0.85$ & $4.75 \pm 0.75$ & $2.25 \pm 0.48^{* *}$ & $1.25 \pm 0.48^{* * *}$ & $1.75 \pm 0.48^{* *}$ \\
\hline Test I (100 mg/kg) & $6.0 \pm 0.41$ & $5.5 \pm 0.87$ & $4.75 \pm 0.48$ & $4.50 \pm 0.64$ & $5.0 \pm 0.71$ \\
\hline Test II (250 mg/kg) & $6.25 \pm 0.62$ & $5.50 \pm 0.96$ & $4.75 \pm 1.03$ & $4.25 \pm 0.48$ & $4.0 \pm 1.08$ \\
\hline Test III $(500 \mathrm{mg} / \mathrm{kg})$ & $6.0 \pm 1.08$ & $5.75 \pm 0.48$ & $3.5 \pm 0.64$ & $3.0 \pm 0.71^{*}$ & $3.25 \pm 1.18$ \\
\hline
\end{tabular}

$*$ indicates $p<0.05, * *$ indicates $p<0.01$, and $* * *$ indicates $p<0.001$ when compared with control.

TABLE 8: Effect of D. candenatensis on Hole Board Test in mice (mean \pm SEM, $n=5$ ).

\begin{tabular}{|c|c|c|c|c|c|}
\hline \multirow{2}{*}{ Group } & \multicolumn{5}{|c|}{ Number of head dips by the mice } \\
\hline & $0 \mathrm{~min}$ & $30 \mathrm{~min}$ & $60 \mathrm{~min}$ & $90 \mathrm{~min}$ & $120 \mathrm{~min}$ \\
\hline Negative control & $30.0 \pm 3.29$ & $32.25 \pm 2.28$ & $32.0 \pm 3.34$ & $32.75 \pm 2.06$ & $32.5 \pm 2.22$ \\
\hline Positive control & $29.75 \pm 1.11$ & $21.0 \pm 1.82^{*}$ & $13.25 \pm 0.85^{* * *}$ & $8.75 \pm 0.85^{* * *}$ & $12.0 \pm 1.08^{* * *}$ \\
\hline Test I (100 mg/kg) & $30.25 \pm 4.30$ & $30.75 \pm 4.03$ & $28.0 \pm 4.06$ & $25.0 \pm 3.02$ & $24.0 \pm 1.9$ \\
\hline Test II (250 mg/kg) & $33.75 \pm 2.32$ & $25.25 \pm 3.12$ & $22.5 \pm 2.53$ & $19.0 \pm 1.96^{* *}$ & $18.5 \pm 1.04^{* *}$ \\
\hline Test III $(500 \mathrm{mg} / \mathrm{kg})$ & $28.25 \pm 3.70$ & $25.5 \pm 1.55$ & $17.5 \pm 1.71^{* * *}$ & $15.0 \pm 2.85^{* * *}$ & $15.0 \pm 1.58^{* * *}$ \\
\hline
\end{tabular}

* indicates $p<0.05, * *$ indicates $p<0.01$, and $* * *$ indicates $p<0.001$ when compared with control.

$\mathrm{K}$ deficiency (vitamin $\mathrm{K}$ is a cofactor in the synthesis of functional factors II, VII, IX, X, and XIII and prothrombin) or liver disease which is attributed to production of plasma protein factors [26]. Extracts containing alkaloids and flavonoids may be acting on the extrinsic cascade of clotting by binding with factors resulting in complex formations which inhibit the conversion of prothrombin to thrombin and finally inhibiting the conversion of the soluble fibrinogen to insoluble fibrin clot $[27,28]$. At $2.0 \mathrm{mg} / \mathrm{ml}$ and $4.0 \mathrm{mg} / \mathrm{ml}$ doses, the mean prothrombin time of blood was measured at 67 and 176 seconds, respectively, which were comparable to warfarin at $0.1 \mathrm{mg} / \mathrm{ml}$ dose. Thus, the study showed that D. candenatensis has exhibited remarkable anticoagulant activity.

Acetic acid induced abdominal contractions cause writhing peripherally in mice within very short time duration. Intraperitoneal administration of acetic acid (0.7\%) causes localized inflammation through the release of endogenous pain mediators where stimulus causes the release of free arachidonic acid from tissue phospholipids due to the action of phospholipase A2 and acyl hydrolases. Prostaglandin, thromboxane, and prostacyclin are synthesized via the cyclooxygenase pathway from arachidonic acid [29]. The released prostaglandins, mainly prostacyclin (PGI2) and prostaglandin E, are responsible for sensation of local pain [30]. Substances that lower the number of writhings in mice demonstrate analgesia by inhibition of prostaglandin synthesis, a peripheral mechanism of pain inhibition. Phenolic and different flavonoids like rutin, quercetin, and luteolin are responsible for analgesic properties [31, 32]. Ethanol extract of $D$. candenatensis considerably lowered the number of writhings in mice with dose dependent manner possibly due to the presence of phenolic and flavonoids agents. The standard drug diclofenac sodium inhibits $76.53 \%$ writhing at a dose of $25 \mathrm{mg} / \mathrm{kg}$ body weight whereas $57.14 \%$ writing inhibition was found at $500 \mathrm{mg} / \mathrm{kg}$ dose of extracts just after 15 minutes of the administration of acetic acid pain inducer (Table 3).

The general toxicity of the crude extract was measured by means of a rapid, simple, and convenient technique using brine shrimp lethality bioassay. Though brine shrimp lethality bioassay does not appertain to any specific pharmacological activity, it provides a reasonably well correlation between cytotoxicity and anticancer activities [33]. Anticancer agent shows maximum level of toxicity in this assay. However, any agent that shows toxicity in this assay might not be an anticancer agent but might be an antimalarial agent or insecticidal agent or molluscicidal agent or larvicidal agent $[33,34]$. 
The sample extracts $\mathrm{LC}_{50}$ was $151.499 \mu \mathrm{g} / \mathrm{ml}$ (Figure 1) and Vincristine sulphate $\mathrm{LC}_{50}$ was $0.645 \mu \mathrm{g} / \mathrm{ml}$ (Figure 2) which showed low level of general toxicity of extract in comparison with standard drug. It has been previously reported that $\mathrm{LC}_{50}$ value above $250 \mu \mathrm{g} / \mathrm{ml}$ indicates weak toxic potentiality [35]. This low level of toxicity might be attributed to the presence of plants flavonoids, tannins, and alkaloids type bioactive metabolite and absence of saponin [36]. Thus, the test extract possibly assured its safety in this assay in relation to its use.

It is well known that inhibition of edema induced by formalin in rats is one of the most suitable test procedures to screen antiarthritic and anti-inflammatory agents, as it closely resembles human arthritis [37]. Injection of formalin causes an immediate and intense spontaneous biphasic nociceptive response through the release of several inflammatory mediators including prostaglandin, prostacyclin, and leukotriene [38]. Early phase is caused by a direct effect of formalin on nociceptors whereas the late phase shows tonic response due to activation of neurons of dorsal horns of the spinal cord [38]. In vivo anti-inflammatory activity of flavonoid and flavone derivatives is via modulation of proinflammatory gene expression, for example, inducible NOS and COX-2. D. candenatensis extract showed maximum percentage of inhibition at 3-4 hours after administration of formalin and then gradually reduces the percentage of paw edema. This test was carried out for 48 hours. Higher dose $(500 \mathrm{mg} / \mathrm{kg})$ showed mainly the highest percentage of inhibition $(36.71 \%-36.84 \%)$ of rats paw edema value. Preliminary phytochemical screening of ethanolic D. candenatensis leaves extract revealed the presence of flavonoids which may be responsible for the observed subacute anti-inflammatory effect [39]. Hence, it is suggested that ethanolic extract of leaves may provide benefits in the management of arthritis by inhibition of paw edema. This is in accordance with the findings reported in the related literature, which have shown intense edema after three hours, mild edema within three days, and no edema at day seven [40].

Depression effect carried out by In Vivo Hypnosis, Open Field, Hole Board, and Hole Cross methods. The Open Field test measures a number of facets of behavior beyond simple locomotion. The Hole Board Test (HBT) is an experimental method used in scientific research to measure anxiety, stress, neophilia, and emotionality in animals. Because of its ability to measure multiple behaviors, it is a popular test in behavioral pharmacology but the results are controversial. Moreover, the validation of anxiety was carried out by measuring external signs, through Hole Cross tests. There are several reports which demonstrated that the alkaloids, glycosides, and flavonoids rich plant extracts possess sedative, anxiolytic, and antiepileptic properties mediated through their affinity with benzodiazepine site of GABAergic complex system or are direct or indirect modulators of this receptor's increases in GABA activity in the brain producing drowsiness and facilitating or maintaining sleep [41-45]. Besides, nonspecific CNS depression can also be attributed by tannin [46]. Therefore it appears that the above-mentioned phytochemicals present in the $D$. candenatensis leaves extract may contribute at least in part to the sedative and hypnotic effects on the CNS. We started our investigation to evaluate CNS depression effects of $D$. candenatensis leaves extract by recording spontaneous locomotors activity of mice in Hole Cross and Open Field tests. In these tests, any agents with sedative activity will cause reduction in the number of movements and interruption in curiosity of the new environment [47]. Our result displayed that the oral administration of test extract at the doses 100, 250 , and $500 \mathrm{mg} / \mathrm{kg}$ caused a marked reduction in number of holes crossed and lethargy to new environment which was reverse for CNS stimulating agent. The suppression effect was found at $30 \mathrm{~min}$ and continued up to $120 \mathrm{~min}$ after administration of leaf extract. All tested doses produced significant inhibition of locomotion. The suppression of locomotors by inducing $D$. candenatensis crude extract referred its potentiality to depress central nerves system [47]. Another important observation was achieved in the Hole Board Test. This test is well-established as a means to assay potential anxiolytic and sedative effects of any agents by observing the exploratory behavior in rodents. Head-dipping behavior of the animals is directly related to their emotional state [48]. Based on this observation, it was suggested that the expression of an anxiolytic state in animals might be reflected by an increase in head-dipping behavior [48] while a decrease in the number of head dips was found to be correlated with the depressant effect $[49,50]$. Our results revealed that the ethanolic extract of $D$. candenatensis caused a dose dependent reduction in head-dip response in the animals from 2 nd observation of the experiment and lasted to 4 th observation, suggesting that the extract possesses sedative activity rather than anxiolytic potentials [47].

Our above findings were further supported by the results observed in thiopental sodium induced sleeping time determination test. This test is a classical method in behavioral pharmacology to investigate the sedative and hypnotic properties. In our study, the acute oral treatment with different doses of $D$. candenatensis extract significantly modified the latency to induce sleep as well as increasing duration of hypnosis induced by thiopental sodium (maximum sleeping time was noted to be $141 \mathrm{minutes}$ at $500 \mathrm{mg} / \mathrm{kg}$ body weight). As expected, similar types of effects were observed by the administration with diazepam at $1 \mathrm{mg} / \mathrm{kg}$ dose. Substantial evidence revealed that the CNS depressant barbiturates, such as thiopental sodium, bind to the barbiturate binding site on the $\mathrm{GABA}_{\mathrm{A}}$ receptor complex and potentiate GABAmediated hyperpolarization of postsynaptic neurons [41]. Our results suggest that there might be a relationship between the sedative effect produced by experimental leaves extract and the sedation inductive capacity of diazepam. Therefore, it is possible that the GABAergic system may participate in the $D$. candenatensis leaves extract-induced enhancement of the effects of thiopental sodium.

\section{Conclusion}

Crude extracts of Dalbergia candenatensis were subjected to phytochemical and pharmacological investigations to validate the traditional use of it. $D$. candenatensis showed wide range of potential source of secondary bioactive metabolites 
that exhibited membrane stabilizing, analgesic, anticoagulant, sedative-hypnotic, subacute inflammatory, and cytotoxic activities. The effect is rapid, long-lasting, and statistically significant at all the experimental doses tested. However, further studies are needed to isolate bioactive compound(s) and elucidate the precise molecular mechanisms in order to establish the safe and effective dosage and, additionally, verify the possibility of its use in the prevention and cure of diseases, contributing to improving the health of the population through increased access to herbal remedies and medicinal plants and their rational use for the pharmacological activities of the experimental plant.

\section{Disclosure}

The included authors are accountable for the writing and contents of the paper.

\section{Conflicts of Interest}

The authors declare no conflicts of interest.

\section{Acknowledgments}

The authors are grateful to Pharmacy Discipline Laboratories, Khulna University, Bangladesh, for permitting their research amenities.

\section{Supplementary Materials}

Figure 2: Supplementary raw data of acetic acid induced writhing (analgesic activity) test in mice. Table 3: Supplementary raw data of acetic acid induced writhing (analgesic activity) test in mice. Table 4: Supplementary raw data of anti-inflammatory activity test. (Supplementary Materials)

\section{References}

[1] A. De Pasquale, "Pharmacognosy: The oldest modern science," Journal of Ethnopharmacology, vol. 11, no. 1, pp. 1-16, 1984.

[2] D. S. Fabricant and N. R. Farnsworth, "The value of plants used in traditional medicine for drug discovery," Environmental Health Perspectives, vol. 109, no. 1, pp. 69-75, 2001.

[3] P. R. Dash, "Phytochemical Screening and Pharmacological Investigations on Hedychium coronarium," 2016.

[4] I. Faridah-Hanum, A. Latiff, K. R. Hakeem, and M. Ozturk, Mangrove Ecosystems of Asia: Status, Challenges and Management Strategies, Springer, 2013.

[5] S. Saha, J. A. Shilpi, H. Mondal et al., "Ethnomedicinal, phytochemical, and pharmacological profile of the genus Dalbergia L.(Fabaceae)," Phytopharmacology, vol. 4, no. 2, 2013.

[6] S. Cheenpracha, C. Karalai, C. Ponglimanont, and A. KanjanaOpas, "Candenatenins A-F, phenolic compounds from the heartwood of Dalbergia candenatensis," Journal of Natural Products, vol. 72, no. 8, pp. 1395-1398, 2009.

[7] M. O. Hamburger, G. A. Cordell, P. Tantivatana, and N. Ruangrungsi, "Traditional medicinal plants of Thailand, VIII. Isoflavonoids of Dalbergia candenatensis," Journal of Natural Products, vol. 50, no. 4, pp. 696-699, 1987.
[8] A. El-Halawany, R. Salah El Dine, M. H. Chung, T. Nishihara, and M. Hattori, "Screening for estrogenic and antiestrogenic activities of plants growing in Egypt and Thailand," Pharmacognosy Research, vol. 3, no. 2, pp. 107-113, 2011.

[9] A. Ghani, Medicinal plants of Bangladesh: chemical constituents and uses, Asiatic society of Bangladesh, 1998.

[10] O. Oyedapo and A. J. Famurewa, "Antiprotease and Membrane Stabilizing Activities of Extracts of Fagara Zanthoxyloides, Olax Subscorpioides and Tetrapleura Tetraptera," International Journal of Pharmacognosy, vol. 33, no. 1, pp. 65-69, 1995.

[11] U. A. Shinde, A. S. Phadke, A. M. Nair, A. A. Mungantiwar, V. J. Dikshit, and M. N. Saraf, "Membrane stabilizing activity - A possible mechanism of action for the anti-inflammatory activity of Cedrus deodara wood oil," Fitoterapia, vol. 70, no. 3, pp. 251$257,1999$.

[12] O. Omodamiro and C. Ikekamma, "In vitro Study of Antioxidant and Anticoagulant Activities of Ethanol Extract of Pandanus tectorius Leaves," International Blood Research Reviews, vol. 5, no. 1, pp. 1-11, 2016.

[13] J. El Hilaly, Z. H. Israili, and B. Lyoussi, "Acute and chronic toxicological studies of Ajuga iva in experimental animals," Journal of Ethnopharmacology, vol. 91, no. 1, pp. 43-50, 2004.

[14] OECD, Acute Oral Toxicity - Acute Toxic Class Method 423 Adopted, Guideline for Testing of Chemicals, 2001, 1-14.

[15] N. N. Biswas, S. Saha, and M. K. Ali, "Antioxidant, antimicrobial, cytotoxic and analgesic activities of ethanolic extract of Mentha arvensis L," Asian Pacific Journal of Tropical Biomedicine, vol. 4, no. 10, pp. 792-797, 2014.

[16] B. N. Meyer, N. R. Ferrigni, J. E. Putnam, L. B. Jacobsen, D. E. Nichols, and J. L. McLaughlin, "Brine shrimp: a convenient general bioassay for active plant constituents," Planta Medica, vol. 45 , no. 5, pp. 31-34, 1982.

[17] C. A. Winter, E. A. Risley, and G. W. Nuss, "Carrageenininduced edema in hind paw of the rat as an assay for antiiflammatory drugs," Proceedings of the Society for Experimental Biology and Medicine, vol. 3, pp. 544-547, 1962.

[18] N. Dehar and R. Walia, "Potentiation of thiopentone sodium induced hypnosis by Berberis aristata in rodents," Asian Journal of Pharmaceutical and Clinical Research, vol. 5, no. 1, pp. 131-133, 2012.

[19] "Central nervous system depressant activity of Diospyros peregrina bark," Oriental Pharmacy and Experimental Medicine, vol. 4, no. 4, pp. 249-252, 2004.

[20] B. Y. Sheikh, S. M. N. K. Zihad, N. Sifat et al., "Comparative study of neuropharmacological, analgesic properties and phenolic profile of Ajwah, Safawy and Sukkari cultivars of date palm (Phoenix dactylifera)," Oriental Pharmacy and Experimental Medicine, vol. 16, no. 3, pp. 175-183, 2016.

[21] S. J. Uddin, J. A. Shilpi, M. T. Rahman, M. Ferdous, R. Rouf, and S. D. Sarker, "Assessment of neuropharmacological activities of Pandanus foetidus (Pandanaceae) in mice," Die Pharmazie-An International Journal of Pharmaceutical Sciences, vol. 61, no. 4, pp. 362-364, 2006.

[22] M. Anisuzzaman, M. Q. Ahsan, M. R. Kuddus, and M. A. Rashid, "Pharmacological Activities of Senna obtusifolia Linn.: A Medicinal Plant of Bangladesh," Bangladesh Pharmaceutical Journal, vol. 17, no. 2, 2015.

[23] H. Sies, T. Schewe, C. Heiss, and M. Kelm, "Cocoa polyphenols and inflammatory mediators.," American Journal of Clinical Nutrition, vol. 81, no. 1, 2005. 
[24] A. T. Oladiji, T. O. Jacob, and M. T. Yakubu, "Anti-anaemic potentials of aqueous extract of Sorghum bicolor (L.) moench stem bark in rats," Journal of Ethnopharmacology, vol. 111, no. 3, pp. 651-656, 2007.

[25] W. Lee, E.-J. Yang, S.-K. Ku, K.-S. Song, and J.-S. Bae, "Anticoagulant activities of oleanolic acid via inhibition of tissue factor expressions," BMB Reports, vol. 45, no. 7, pp. 390-395, 2012.

[26] W. Blonski, T. Siropaides, and K. R. Reddy, "Coagulopathy in liver disease," Current Treatment Options in Gastroenterology, vol. 10, no. 6, pp. 464-473, 2007.

[27] H. H. Kashani, E. S. Hoseini, H. Nikzad, and M. H. Aarabi, "Pharmacological properties of medicinal herbs by focus on secondary metabolites," Life Science Journal, vol. 9, no. 1, pp. 509-520, 2012.

[28] M. B. Engler and M. M. Engler, "The vasculoprotective effects of flavonoid-rich cocoa and chocolate," Nutrition Research, vol. 24, no. 9, pp. 695-706, 2004.

[29] "Antinociceptive activity of some Bangladeshi medicinal plant extracts," Oriental Pharmacy and Experimental Medicine, vol. 6, no. 2, pp. 96-101, 2006.

[30] C. Talukder, S. Saha, S. Adhikari, H. K. Mondal, M. Khirul Islam, and M. Anisuzzman, "Evaluation of antioxidant, analgesic and antidiarrhoeal activity of Flacourtia jangomas (Lour.) Raeusch. leaves," Pharmacologyonline, vol. 3, pp. 20-28, 2012.

[31] R. Arslan, N. Bektas, and Y. Ozturk, "Antinociceptive activity of methanol extract of fruits of Capparis ovata in mice," Journal of Ethnopharmacology, vol. 131, no. 1, pp. 28-32, 2010.

[32] D. D. Orhan, A. Hartevioğlu, E. Küpeli, and E. Yesilada, "In vivo anti-inflammatory and antinociceptive activity of the crude extract and fractions from Rosa canina L. fruits," Journal of Ethnopharmacology, vol. 112, no. 2, pp. 394-400, 2007.

[33] "Antioxidant, antinociceptive activity and general toxicity study of Dendrophthoe falcata and isolation of quercitrin as the major component," Oriental Pharmacy and Experimental Medicine, vol. 6, no. 4, pp. 355-360, 2006.

[34] S. Dusen, C. Aydin, H. Y. Gul, C. Ozay, O. Dusen, and R. Mammadov, "In vitro cytotoxic activities ofCyclamen L.(Primulaceae) ethanol extracts from Turkey," Fresenius Environmental Bulletin, vol. 25, no. 12 A, pp. 6224-6228, 2016.

[35] R. L. Fabri, D. S. De Sá, A. P. O. Pereira, E. Scio, D. S. Pimenta, and L. M. Chedier, "Antimicrobial, antioxidant and cytotoxicity potential of Manihot multifida (L.) Crantz (Euphorbiaceae)," Anais da Academia Brasileira de Ciências, vol. 87, no. 1, pp. 303311, 2015.

[36] A. A. Musa, "Cytotoxicity activity and phytochemical screening of Cochlospermum tinctorium perr ex A. Rich rhizome," Journal of Applied Pharmaceutical Science, vol. 2, no. 7, pp. 155159, 2012.

[37] R. A. Greenwald, "Animal models for evaluation of arthritis drugs," Methods and Findings in Experimental and Clinical Pharmacology, vol. 13, no. 2, pp. 75-83, 1991.

[38] A. Tjølsen, O.-G. Berge, S. Hunskaar, J. H. Rosland, and K. Hole, "The formalin test: an evaluation of the method," PAIN, vol. 51, no. 1, pp. 5-17, 1992.

[39] H. P. Kim, K. H. Son, H. W. Chang, and S. S. Kang, "Antiinflammatory plant flavonoids and cellular action mechanisms," Journal of Pharmacological Sciences, vol. 96, no. 3, pp. 229-245, 2004.

[40] S. Perrot, G. Guilbaud, and V. Kayser, "Effects of intraplantar morphine on paw edema and pain-related behaviour in a rat model of repeated acute inflammation," PAIN, vol. 83, no. 2, pp. 249-257, 1999.
[41] S. Fernández, C. Wasowski, A. C. Paladini, and M. Marder, "Sedative and sleep-enhancing properties of linarin, a flavonoid-isolated from Valeriana officinalis," Pharmacology Biochemistry \& Behavior, vol. 77, no. 2, pp. 399-404, 2004.

[42] P. Kahnberg, E. Lager, C. Rosenberg et al., "Refinement and evaluation of a pharmacophore model for flavone derivatives binding to the benzodiazepine site of the GABAA receptor," Journal of Medicinal Chemistry, vol. 45, no. 19, pp. 4188-4201, 2002.

[43] E. Trofimiuk, A. Walesiuk, and J. J. Braszko, "St John's wort (Hypericum perforatum) diminishes cognitive impairment caused by the chronic restraint stress in rats," Pharmacological Research, vol. 51, no. 3, pp. 239-246, 2005.

[44] R. Awad, F. Ahmed, N. Bourbonnais-Spear et al., "Ethnopharmacology of Q'eqchi' Maya antiepileptic and anxiolytic plants: effects on the GABAergic system," Journal of Ethnopharmacology, vol. 125, no. 2, pp. 257-264, 2009.

[45] R. Estrada-Reyes, C. López-Rubalcava, L. Rocha, G. Heinze, A. R. González Esquinca, and M. Martínez-Vázquez, "Anxiolyticlike and sedative actions of Rollinia mucosa: possible involvement of the GABA/benzodiazepine receptor complex," Pharmaceutical Biology, vol. 48, no. 1, pp. 70-75, 2010.

[46] R. N. Takahashi, T. C. M. De Lima, and G. S. Morato, "Pharmacological actions of tannic acid; II. Evaluation of CNS activity in animals," Planta Medica, vol. 4, pp. 272-275, 1986.

[47] M. Moniruzzaman, M. Atikur Rahman, and A. Ferdous, "Evaluation of sedative and hypnotic activity of ethanolic extract of Scoparia dulcis Linn.," Evidence-Based Complementary and Alternative Medicine, vol. 2015, Article ID 873954, 6 pages, 2015.

[48] H. Takeda, M. Tsuji, and T. Matsumiya, "Changes in headdipping behavior in the hole-board test reflect the anxiogenic and/or anxiolytic state in mice," European Journal of Pharmacology, vol. 350, no. 1, pp. 21-29, 1998.

[49] S. E. File and S. Pellow, "Intrinsic actions of the benzodiazepine receptor antagonist, Ro 15-1788," Psychopharmacology, vol. 88, no. 1, pp. 1-11, 1986.

[50] H. Viola, C. Wasowski, M. L. De Stein et al., "Apigenin, a component of Matricaria recutita flowers, is a central benzodiazepine receptors-ligand with anxiolytic effects," Planta Medica, vol. 61, no. 3, pp. 213-216, 1995. 


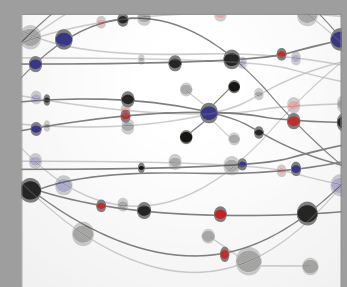

The Scientific World Journal
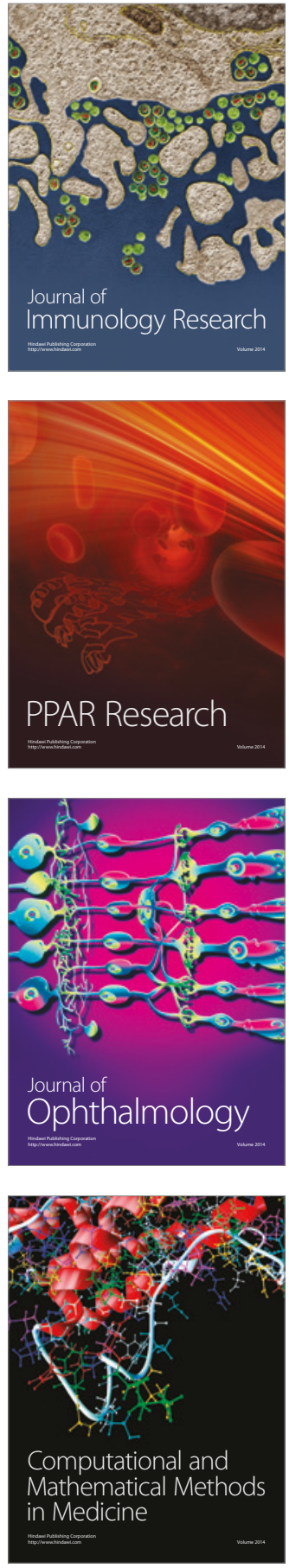

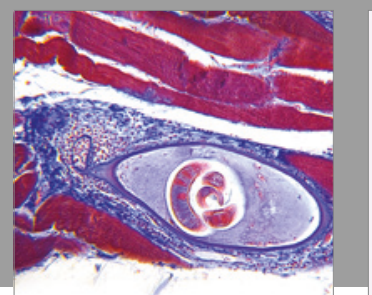

Gastroenterology Research and Practice
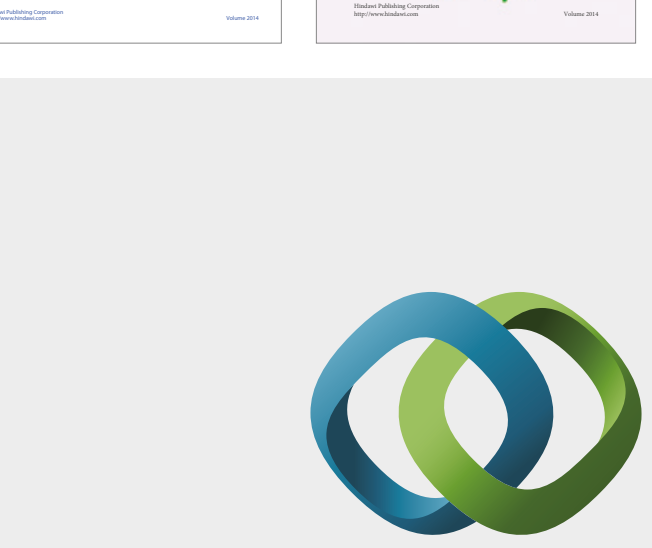

\section{Hindawi}

Submit your manuscripts at

https://www.hindawi.com
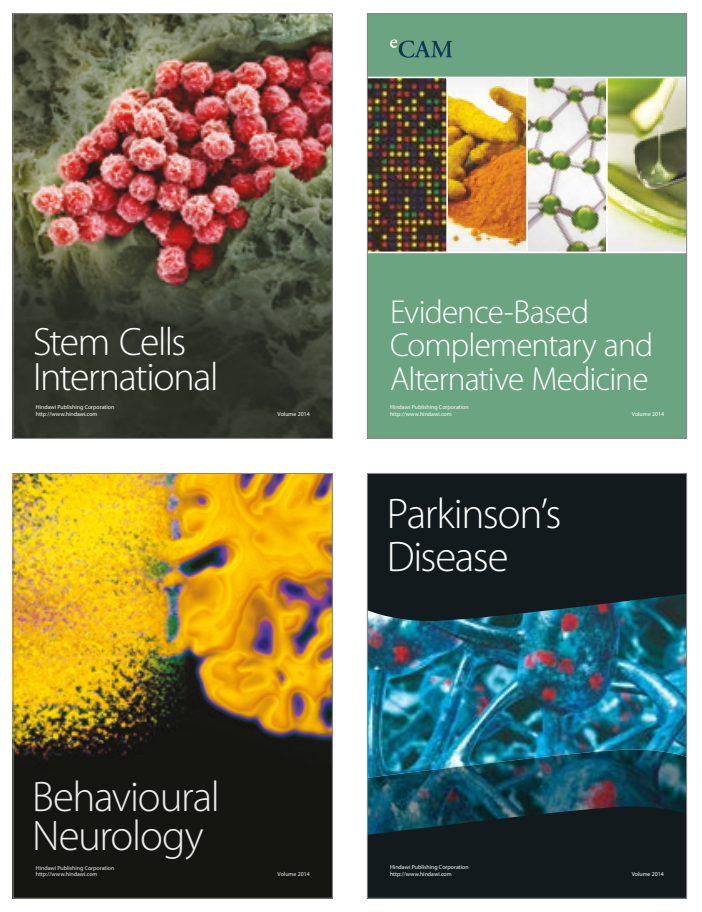
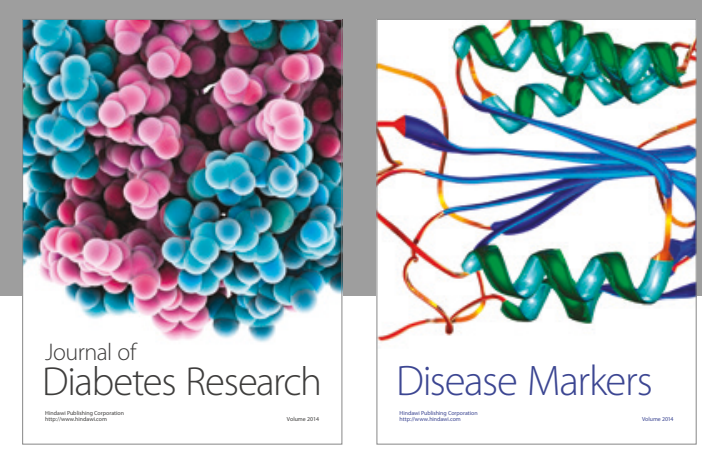

Disease Markers
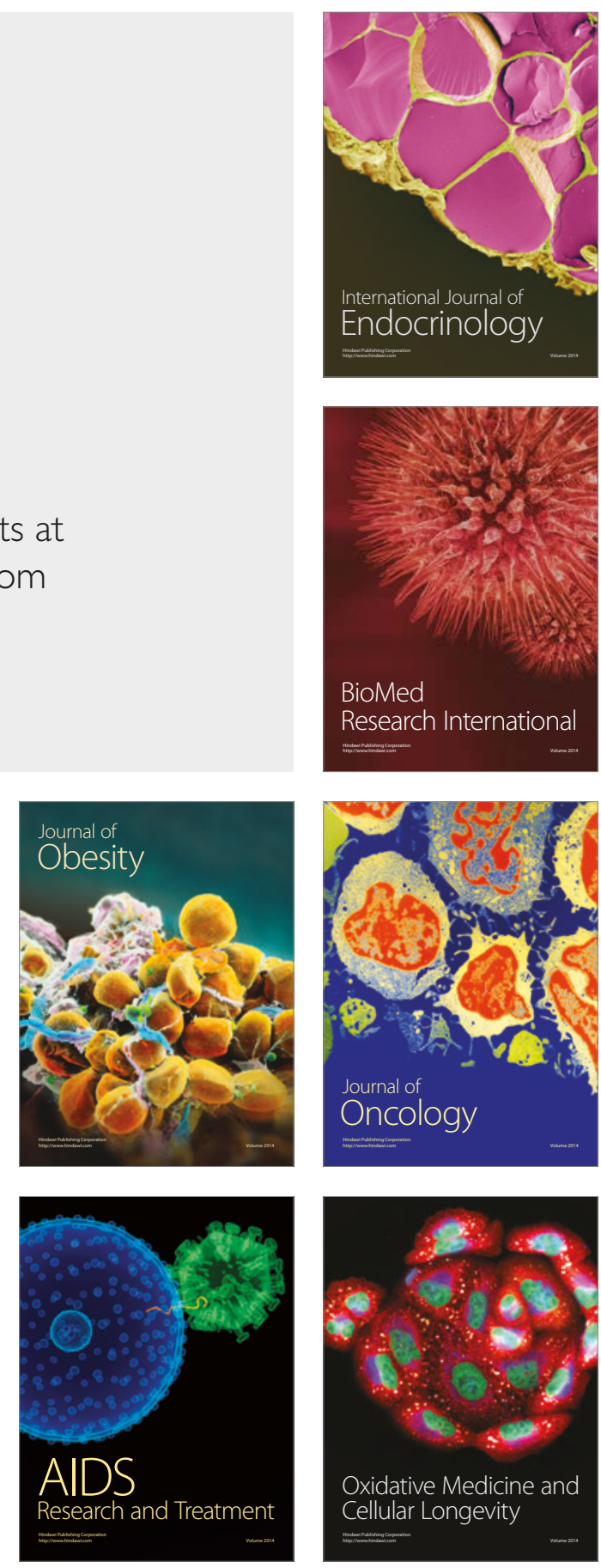